\title{
Epizootology, Species Composition, Peculiarities of Biological Revolution and Population Ecology of Pathogens of Cattle Hypodermosis in the Chechen Republic
}

\author{
Vatsaev Sh.V. \\ Department of Veterinary Medicine \\ and Zoo Engineering \\ Chechen State University \\ Grozny, Russia \\ vac-60@mail.ru \\ Baisarova Z.T. \\ Department of Biological Research \\ Kh. Ibragimov Complex Institute \\ of the Russian Academy of Science \\ Grozny, Russia \\ Chgu@mail.ru
}

\author{
Jamalova A.Z. \\ Department of Biological Research \\ Kh. Ibragimov Complex Institute \\ of the Russian Academy of Science \\ Grozny, Russia \\ dzhamalovam@list.ru
}

Plieva A.M.

Department of Biological Research

Kh. Ibragimov Complex Institute

of the Russian Academy of Science

Grozny, Russia

Ingush State Universty

Nazran, Russia

aishet57@mail.ru

\author{
Saidullaev A-Kh.A. \\ Department of Biological Research \\ Kh. Ibragimov Complex Institute \\ of the Russian Academy of Science \\ Grozny, Russia \\ arbi-68@bk.ru
}

\begin{abstract}
The article presents data on the distribution, peculiarities of the biological development and population ecology of the pathogens of cattle hypodermosis in the Chechen Republic, extensiveness and intensity of invasion in different climatic zones of the Chechen Republic; dependence of the epizootic situation on the vertical zoning of the concentration of animals within the context of the reduction in the population of the parasitifer. The periods of the seasonal dynamics of the rise in the number of insects are described, which indicates when the studied species is involved in the life of the biocenosis in the most active way; that is important when planning therapeutic and preventive measures. The data on the daily activity of $H$. bovis and $H$. lineatum are researched and presented; they include migrations, attacks on animals, reproduction, with the interleaved rest states during the day, as well as the role of environmental factors as regulating mechanisms of the insects' activity that can influence their behaviour and level of activity. The impact of biotic, abiotic and anthropogenic factors on the pathogens of cattle hypodermosis which determine the successful existence of the species in the given area is researched.

In the Chechen Republic the cattle hypodermosis is widespread. Animals of all sex-age groups can be infected, most often up to the age of two (E.I. - 35.7\%, I.I. - 12.0 specimens per
\end{abstract}

animal, seldom - older than two), - older than two (E.I. - 12.3\%, I.I. - 9.3 specimens per animal).

Keywords - hypodermosis, epizootology, developmental biology, population ecology, extensiveness of invasion (E.I.), intensity of invasion (I.I.), infestation, ecological factors, biocenosis, entomofauna.

\section{INTRODUCTION}

In recent years the reorganization of the agricultural production has been accompanied by the reduction in the number of systematic treatment-and-prophylactic and veterinary-sanitary measures aimed at reducing the number of pathogens of the livestock animals' parasitic diseases.

The Chechen Republic has great potential for the development of livestock breeding. However, one of the important deterrents is the widespread parasitic diseases of livestock animals including cattle hypodermosis. The economic damage caused by hypodermosis is conditioned by decreased meat and milk production, decreased quality of the rawhide, and the birth of a weakened livestock population. 
Infested animals and the weakened young livestock born by them can easily catch other diseases of contagious and noncontagious etiology.

Hypodermosis is a chronic disease caused by the larvae of the hypodermic gadflies Hypoderma bovis De Geer and Hypoderma lineatum De Villers; it is widespread in the Russian Federation and many countries of the world, causing significant economic damage to livestock breeding [6].

The immense area occupied by hypodermosis pathogens and the need to ensure the veterinary safety in relation to hypodermosis caused the necessity of carrying out the complex of basic and applied research.

The research of the characteristics of the development of hypodermosis pathogens contributed to the success in developing measures to control them.

It is quite obvious that any integrated system of controlling the parasitic diseases of livestock should be based on etiopathogenetic conceptions of diseases, knowledge of the species composition, biology and population ecology of parasitic pathogens, taking into account the choice of means and methods of their application, which can provide the best treatment and prophylactic efficacy in the light of the season and climatic conditions, species characteristics of livestock, economic and environmental factors; besides, this system is a significant means of increasing the number of cattle, reducing the loss of animals' dairy and meat productivity, improving the quality of rawhide [6].

The above mentioned factors predetermined the need to study the regional epizootology of cattle hypodermosis in the Chechen Republic, to determine the species composition of the pathogens of this disease, to study their biology and population ecology in order to develop an integrated system to control hypodermosis on the basis of the improved means and methods of treatment, prevention of this disease and implementation of the results in the veterinary practice.

The objectives of the given research are:

- to study the distribution of hypodermosis in various climatic zones of the Chechen Republic; the dependence of the epizootic situation on the vertical zoning of the animals' concentration in the light of the reduction in the number of the parasitifer population;

- to study the species composition and biological peculiarities of the development and population ecology of the pathogens of cattle hypodermosis, which contributed to the success in the development of measures to control this disease on the basis of the improved means and methods of treatment and prevention and the implementation of the research results in the veterinary practice;

- to develop theoretical and practical principles of protecting livestock from hypodermosis.

The study of these issues having great scientific and practical importance remains in the field of view of veterinary science and practice, and this knowledge and successful controlling the diseases create the prerequisites for optimizing the process of preventive and treatment measures to combat hypodermosis, specifying the terms and frequency of animal treatments in different climatic conditions. The knowledge of these aspects is a significant means of increasing the number of cattle, reducing the loss of animals' dairy and meat productivity, improving the quality of animal products and rawhide, ensuring the veterinary safety in relation to contagious diseases of the livestock.

\section{METHODS AND MATERIALS}

According to the geological structure and terrain, the territory of the Chechen Republic is divided into three climatic zones: lowland, foothill and mountainous; each of them has various surface structure, climate characteristics, soil, vegetation distribution and animal world [5].

In the process of research an integrated approach was used, which included such methods as: epizootological examination, morphological and experimental research in veterinary medicine. The data of the veterinary reports were used.

In order to study the epizootology of the hypodermosis the expeditionary and stationary observations at the livestock farms of the republic were made.

The clinical studies were conducted according to the currently accepted methods. The diagnosis was made on the basis of the clinical examination of the infested animals. The visual inspection and palpation of the skin of the animals' dorsal surface with fingers, the presence of nodules and scabs allowed determining the percentage of the animals infested by gadflies - the extensiveness of invasion (E.I.\%); the calculation of gadflies' larvae by a mean of one animal showed the intensity of invasion (I.I.).

\section{RESULTS}

The analysis of the epizootic state and the results of the authors' own research indicate that cattle hypodermosis is widespread in the Chechen Republic.

It is known that in the places of mass livestock management hypodermosis is spread more widely and it attacks animals of all sex-age groups [3].

In recent years in the Chechen Republic a high level of ixodic ticks' attack on the cattle has been recorded; ixodic ticks are carriers of a number of protozoan animal diseases (babesiosis, piroplasmosis, theileriosis, etc.). In this regard, in the republic the cattle are subjected to regular treatments with insectoacaricides during the spring-summer period every year. Thus, the goal of destroying the variety of ectoparasites is achieved in a single working method. It was found out that the treated animals had a significantly lower level of extensiveness and intensity of skin-gadfly infestation than the untreated ones.

The studies were carried out in eleven settlements located in the lowland, foothill and mountain zones. 1961 cattle were examined, including 842 animals older than two and 1119 ones under the age of two. 
The extensiveness of the gadfly invasion (E.I.) among the treated animals older than 2 was $2.13 \%$; the intensity of invasion (I.I.) was 5.3 specimens per animal. Among the animals under the age of 2 E.I. was $3.15 \%$, I.I. -8.2 specimens per animal.

Among the untreated animals under the age of 2 the rate of extensiveness of the gadfly invasion was $35.7 \%$, the intensity of invasion was 12.0 larvae per animal. Lower rates of E.I. and I.I. were registered among the adult animals: E.I. accounted for $12.3 \%$, and I.I. -9.3 larvae per animal.

The data of our research indicate that in the studied climatic zones hypodermosis is characterized by various levels of invasion extensiveness and intensity. In the lowland zone the animals' skin-gadfly infestation is more common $(48 \%)$ than in the foothill and mountain zones (the foothill zone $29 \%$, the mountain zone $-23 \%$ ).

It should be noted that the levels of extensiveness and intensity of the skin-gadfly invasion depend on the well-timed implementation of the integrated anti-gadfly measures, natural and climatic conditions, the specificity of cattle breeding and the peculiarities of the animal management to a certain extent $[2,4]$.

The development of the clinically apparent signs of hypodermosis in various climatic zones of the Chechen Republic has different time limits.

In the lowland zone the larvae of the warble fly form cattle's nodules during the period from January to May; the greatest intensity is noted in March.

In the foothill zone the larvae's moving to the surface of the skin is registered from February to June; the maximum percentage is seen from March to April.

In the mountainous area among the young and adult cattle the nodules with the larvae of the ox warble fly are formed from March to July; the maximum percentage is seen from April to May.

While studying the epizootic situation of hypodermosis in the Chechen Republic, the data of veterinary reports about the hypodermosis recordings in different climatic zones over the past three years were analyzed.

This analysis shows that, according to the veterinary reports, the extensiveness of the skin-gadfly infestation of the cattle in the Chechen Republic varies from 0.3 to $23.4 \%$.

In the course of the research of the species composition, peculiarities of biology and distribution of hypodermosis pathogens in the Chechen Republic two types of gadflies were discovered: Hypoderma bovis De Geer - a common warble fly (an ox warble fly) and Hypoderma lineatum De Villers - a southern warble fly (a striped ox warble fly). The first one is widespread, the second one is more common in the lowland and foothill zones at the altitude of up to 500 meters above sea level. Their quantitative ratio is determined by the location above sea level. It was determined that in the lowland zone the number of the studied species has the following ratio: the ox warble fly accounts for $52.3 \%$, the striped ox warble fly $47.7 \%$; in the foothill zone the ox warble fly makes up $60.7 \%$, the striped ox warble fly $-39.3 \%$; in the mountainous zone the ratio is as follows: $96.9 \%$ and $3.1 \%$.

The periods of seasonal dynamics of the rise in the number of insects were studied; they indicate when the researched species are involved in the life of the biocenosis in the most active way, this information is important when planning treatment and preventive measures.

It was found out that the number of the winged insects (hypodermosis causative pathogens) is relatively low.

In the years when spring comes early the emergence of gadflies begins in the second or third decade of April in the lowland zone, in the foothill and mountainous zones - in the first or second decades of May [1].

The highest rise in the number of insects was recorded in the third decade of May, in the first and second decades of June. Then during the third decade of June and two decades of July a decrease in the number of insects was noted, which, in the authors' opinion, was conditioned by the natural death of gadflies. The end of the gadflies' emergence was recorded in October-November (the lowland zone), September-October (the foothill and mountainous zones).

The number of the winged causative pathogens of cattle hypodermosis is largely determined by the meteorological activity in their habitat zone, anthropogenic impact on the populations of hypodermosis pathogens, which is conditioned by the extensive use of acaricides during this period allowing the vets to kill ixodic ticks parasitizing on cattle. In the third decade of July and the first decade of August a new peak in the growth of the number of gadflies is noted (in the lowland zone). In September-October, a progressive decline in the number of insects is reported.

A single increase in the number of insects was recorded in the foothill and mountain zones.

In the years when spring comes late and summer is cool and rainy, the winged gadflies emerge in the second or third decade of June, which has a regulating effect on the number of their population, extensiveness and intensity of hypodermal infestation [1].

The daily activity of $H$. bovis and $H$. lineatum was researched; it included migrations, attacks on animals, reproduction and interleaved rest states during the day. The regulating mechanism of the insects' activity is environmental factors that may influence their behavior and activity level. The impact of biotic, abiotic and anthropogenic factors on the causative pathogens of cattle hypodermatosis largely determines the success of the species' existence in the given area. While researching the ecological factors, it was found out that the daily activity of gadflies depends on changes in temperature and humidity. On sunny days the flying of gadflies was noted at the temperature of $7-9^{\circ} \mathrm{C}$, on cloudy days - at $13-15^{\circ} \mathrm{C}$. In spring the flying of gadflies began at 9-11 a.m., in summer - at 6-8 a.m. During the summer time the maximum activity of the insects was recorded at 8-12 a.m. When the heat came (1-4 p.m.) the activity of gadflies sharply decreased or ceased. From 4-5 p.m. to 8 p.m. the activity of gadflies' attacking the cattle increased slightly, but it was 
lower than in the morning. In autumn the flying of gadflies was recorded from 10-12 a.m. to 3-4 p.m.

It was determined that a short-term decrease in the air temperature up to $-2^{\circ} \mathrm{C}$ (spring-autumn frosts) did not kill them; when the temperature increased their activity was the same. The insects died at the temperature of $-5^{\circ} \mathrm{C}[1]$

Observing the insects every decade, the authors found out that imagoes of hypodermic gadflies more often fly around animals on warm sunny days from 8 a.m. to 1 p.m. and from 5 p.m. to 8 p.m. It was during these periods when the maximum number of "centres of anxiety" in cattle herds was recorded [1].

\section{CONCLUSION}

In the Chechen Republic two types of gadflies parasitize on cattle: Hypoderma bovis De Geer (a common warble fly, an ox warble fly) and Hypoderma lineatum DeVillers (a striped ox warble fly).

The causative pathogens of hypodermosis have a spotty territorial distribution. $\mathrm{H}$. bovis is registered in all parts. $\mathrm{H}$. lineatum is found mainly in the lowland and foothill zones of the republic. The number of species is demonstrated by the ratio: in the lowland zone the ox warble fly accounts for $52.3 \%$, the striped ox warble fly $-47.7 \%$; in the foothill zone the ox warble fly makes up $60.7 \%$, the striped ox warble fly $39.3 \%$; in the mountainous zone the ratio is as follows: $96.9 \%$ and $3.1 \%$.

The emergence of gadflies in different climatic zones of the republic is recorded from the second decade of May to the second decade of September.

The end of the gadflies' flying was recorded in OctoberNovember (the lowland zone), September-October (foothill and mountainous zones).

In the Chechen Republic the cattle hypodermosis is widespread. Animals of all sex-age groups can be infected, most often up to the age of two (E.I. - 35.7\%, I.I. - 12.0 specimens per animal, seldom - older than two), - older than two (E.I. - 12.3\%, I.I. - 9.3 specimens per animal).

The extensiveness of the gadfly invasion (E.I.) among the treated animals older than 2 was $2.13 \%$, the intensity of invasion (I.I.) was 5.3 specimens per animal. Among the animals under the age of 2 E.I. was $3.15 \%$, I.I. -8.2 specimens per animal.

Among the untreated animals under the age of 2 the rate of extensiveness of the gadfly invasion was $35.7 \%$; the intensity of invasion was 12.0 larvae per animal. Lower rates of E.I. and I.I. were registered among the adult animals: E.I. accounted for $12.3 \%$, and I.I. - 9.3 larvae per animal.

\section{References}

[1] Sh.V. Vatsaev, Hypodermatosis of Cattle (Epizootology, Species Composition, Population Ecology) and Development of Measures to Control It in the Chechen Republic, thesis for a Candidate degree in veterinary, St. Petersburg, p. 128, 2008.

[2] D.I. Blagoveshchensky, E.N. Pavlovsky, On the Biology of the Warble Fly (N. bovis De Geer) and Measures to Control, Publishing house of applied entomology, vol. 4, pp. 371-399, 1930.

[3] A.A. Nepoklonov, T. Khipe, H. Shplistezer, C. Dorzh, Diseases of Animals Caused by Gadflies, Mocow, 1980, p. 260.

[4] L.F. Romashova, Terms of Development of a Cattle Skin Gadfly in Kyrgyzstan and New Data on Them in Biology, Proceedings of Kyrgyz. NIIZHIV, vol. 13, 1958, pp. 69-78.

[5] V.V. Ryzhikov, P.S. Anisimov et al, Nature of the Chechen-Ingush Republic, Its Protection and Sustainable Use, Grozny: Chechen-Ingush Publishing House, 1991, p. 160.

[6] V.P. Tolokonnikov, S.N. Lutsuk, Cattle Hypodermosis and Measures of Its Control: Rcommendations for Veterinarians, Stavropol: AGRUS, p.20, 2010.

[7] Sh.V. Vatsaev, H.I. Bersanova, O.V. Didenko, "Cattle Hypodermosis, Means and Methods of Controlling It in the Chechen Republic. Scientific Support of Socio-Economic Development and Economic Security of the Agro-Industrial Complex", Bulletin of the Russian Academy of Agricultural Sciences, Moscow, 2011, pp. 311-315.

[8] Sh.V. Vatsaev, "Species Composition, Biology of Pathogens of Cattle Hypodermatosis in the Chechen Republic", Issues of the Statutory Regulation in Veterinary Medicine, no. 2, 2016, ppP.54-58.

[9] Sh.V. Vatsaev, V.P. Tolokonnikov, "Studying the Seasonal Dynamics and Terms of Development of Larvial Phases of Cattle Hypodermic Pathogens in the Chechen Republic", Russian Parasitological Journal, vol. 37, no. 3, 2016, pp. 304-311.

[10] Sh.V. Vatsaev, O.Yu. Chernykh, A.A. Lysenko, M.G. Konovalov, "Evaluation of Biochemical Blood Parameters at Nodular Dermatitis of Cattle in the Chechen Republic", Proceedings of the Kuban State Agrarian University, vol. 2 (65), 2017, pp. 101-107. 